\title{
Introduction: reinventing the welfare state
}

\author{
A. Lans Bovenberg • Bas Jacobs • \\ Ruud A. de Mooij
}

Published online: 4 December 2007

(C) The Author(s) 2007

European welfare states are under pressure due to aging, skill-biased technological change, globalisation and increasing heterogeneity (migration, work and cohabitation patterns). Indeed, the demand for public spending on pensioners and education increases, redistribution toward low skilled workers rises and taxation and income redistribution are becoming more distortionary as individuals can more easily adapt their behaviour to government policies. At the same time, welfare states are increasingly blamed for sustained inactivity among benefit recipients, elderly workers, lowskilled individuals, and women. In light of these developments and trends, the Network for Studies on Pensions, Aging and Retirement (Netspar), CPB Netherlands Bureau for Economic Policy Analysis and the Dutch Social Economic Council organised a conference on 'Reinventing the Welfare State', from which this special issue contains five papers. The first paper explores how globalisation interacts with European welfare states. The next two papers deal with the relationship between current welfare state designs in Europe and their economic outcomes, with an emphasis on the Scandinavian countries. The final two papers analyse specific options for welfare state reform.

\footnotetext{
A.L. Bovenberg University of Tilburg, P.O. Box 90153, 5000 LE Tilburg, The Netherlands e-mail: a.1.bovenberg@uvt.nl

B. Jacobs

Erasmus University Rotterdam, P.O. Box 1738, 3000 DR Rotterdam, The Netherlands e-mail: bjacobs@few.eur.nl

R.A. de Mooij ( $\varangle)$

Program manager Welfare State, CPB Netherlands Bureau for Economic Policy Analysis, P.O. Box 80510, 2508 GM The Hague, The Netherlands e-mail: R.A.de.Mooij@cpb.nl
} 
Atkinson explores the impact of globalisation, which tends to intensify international competition and comes along with skill-biased technological change. Globalisation may weaken the position of low-skilled workers, either due to outsourcing of production activities to countries with an abundance of low-skilled labour, or due to new labour-saving technologies. With European labour-market rigidities that fix real low-skilled wages, globalisation will cause increases in low-skilled unemployment, rather than 'working poor'. Atkinson challenges this traditional view. According to the standard 2-good, 2-factor and 2-country Hecksher-Ohlin model, globalisation either increases wage inequality or European low-skilled unemployment, but not both at the same time as a result of factor-price equalisation. Atkinson offers a first step to resolve this issue by developing a richer $3 \times 3 \times 3$ model with three countries (US, Europe and a newly industrialised country), three sectors (an intermediate and a final traded good and a non-tradable service) and three production factors (skilled and unskilled labour and capital). Apart from explaining the simultaneous occurrence of increasing wage inequality and increasing low-skilled unemployment rates due to globalisation, the model modifies several other major conclusions of the standard $2 \times 2 \times 2$ model. First, a larger US services sector may have cushioned the impact of globalisation on low-skilled unemployment. Second, reductions in the physical capital stock can easily result in a 'bazaar economy', in which low-skilled production work is outsourced. Third, investment in education and skill acquisition are important to protect European welfare states by reducing the vulnerability of the tax base against the forces of globalisation.

Esping-Andersen emphasises that the major challenge for European countries is to contain the growing dispersion in earning abilities. Skill-biased technical change and globalisation are the main driving forces on the demand side of the labour market. However, skill dispersion on the supply side of the labour market is also growing due to low-skilled migrant populations. Reducing skill deficits is crucial to prevent long-lasting poverty and welfare state dependency, which is often transmitted within families across generations. A growing body of evidence is discussed arguing that social origins are a key in explaining socio-economic mobility. Indeed, family income, family structure, parental dedication, and a child's learning environment are critical determinants of educational outcomes and career developments. Esping-Andersen emphasises the importance of investments in early childhood in view of the large returns on these investments. Public spending should, therefore, be redirected toward helping families to invest in their children at a young age. To achieve equal socio-economic outcomes in Europe, Esping-Andersen strongly favours a Nordictype welfare state with universally accessible programs that receive broad political support. They are characterised by considerable redistribution to the poor, generous facilities for mother's employment through public childcare and publicly paid leave arrangements.

Andersen takes a more critical stance on the Scandinavian 'cradle to grave' model of the welfare state, by focusing on the trends and developments that undermine its financial sustainability. The Nordic model is based on universal entitlements to generous public-sector provisions and high taxes to finance these provisions. Entitlements are not unconditional but directed toward achieving high labour-market participation rates. Although Scandinavian countries perform well in terms of labour-market participation, unemployment and income inequality, Andersen argues that the Nordic 
countries face three major challenges for the future. First, aging increases public spending on old-age provisions. The demographic challenge calls for reforms that help increase actual retirement ages, such as reforming early retirement schemes, sickness and disability benefits and raising the statutory pension age. Second, Andersen describes a 'growth dilemma'. Technical change results in rising real prices of the welfare state due to the Baumol-effect. Technical changes are also skill-biased, which undermines the labour market prospects of the low-skilled. The Wagner-effect increases demand for public services, in particular health care and education, which are publicly financed. At the same time, growth tends to be increasingly consumed in the form of leisure, which causes an erosion of the tax base. Thus, growth constitutes a risk to public finances in Scandinavia. The third challenge originates in globalisation. Especially a more mobile tax base and the attractiveness of welfare states to low-skilled migrants put pressure on the financial viability of Scandinavian welfare states.

Bovenberg, Hansen and Sorensen discuss individual savings accounts as an alternative for collectively organised social insurance, which is still common in today's European welfare states. Computations for Denmark reveal that three-quarters of welfare-state expenditures do not involve redistribution from the lifetime rich to the lifetime poor, but are, in fact, transfers that smooth income over the life cycle of individual taxpayers. Bovenberg, Hansen and Sorensen argue that smoothing of consumption can be organised more efficiently through the use of obligatory individual savings accounts. Due to larger population heterogeneity, individuals can more easily adapt their behaviour to government programs and moral hazard in social insurance increases in more complex societies. The authors discuss various areas in which savings accounts can play a useful role, such as pensions, healthcare spending, university tuition, (short-term) unemployment insurance, (short-term) sickness insurance, child benefits, and parental leave benefits. By strengthening the actuarial fairness of social insurance, individual saving accounts enhance labour-market incentives and reduce moral hazard without substantially increasing inequality in lifetime incomes. For this to be possible, the accounts should be combined with a borrowing facility to alleviate liquidity constraints, and a minimum public pension to guarantee a minimum lifetime income. Moreover, mandatory saving is required to prevent moral hazard associated with the borrowing facility and to cope with lack of self-control and myopia of individuals.

De Mooij explores how European governments can potentially improve the equity-efficiency trade-off. Individualisation, changing work patterns, especially of women and changes in household composition add to larger heterogeneity in society. Whereas Bovenberg et al. study how to reduce moral hazard in the spending side of the public budget, De Mooij investigates various options for efficiency enhancing tax-reforms, which generate more employment. De Mooij uses the key insights from the optimal tax theory to identify potentially promising directions for reform, such as in-work tax credits and tax reductions for secondary earners. To explore these reforms, he analyses reforms in the Dutch tax-benefit system by using an applied general equilibrium model for the Netherlands. The model encompasses tax distortions at the intensive and extensive margins of labour supply, distinguishes between males and females, models part-time work and derives equilibrium unemployment 
as a function of various institutional variables. Elasticities are calibrated on the basis of existing empirical evidence, while population densities are calibrated with Dutch micro data. The analysis reveals that selective in-work tax relief for elastic secondary earners and for low-skilled workers have the potential to raise employment without sacrificing equality in the Netherlands. However, a flat income tax structure, possibly combined with a negative income tax, tends to worsen the equity-efficiency trade-off.

This completes our summary of this special issue. We invite readers to study the papers in this issue in detail. We would like to thank the authors of the papers, the discussants at the conference, and especially, the referees for their cooperation in making this issue possible.

Open Access This article is distributed under the terms of the Creative Commons Attribution Noncommercial License which permits any noncommercial use, distribution, and reproduction in any medium, provided the original author(s) and source are credited. 